\title{
Relationships between the Conception Rate of Estrus Synchronization Using Estradiol Benzoate and CIDR (Progesterone) and Other Parameters in Holstein Lactating Dairy Cows
}

\author{
Hiroshi MIURA ${ }^{1)}$, Satoko KOTANI ${ }^{1)}$, Masayuki KOHIRUIMAKI ${ }^{2,3)}$, Hiromichi OHTSUKA ${ }^{2}$, \\ Motohiro KIKUCHI' ${ }^{1)}$ and Yoji OHNAMI ${ }^{1)}$
}

\author{
${ }^{1)}$ Department of Clinical Veterinary Theriogenology, ${ }^{2)}$ Department of Veterinary Internal Medicine, School of Veterinary \\ Medicine and Animal Sciences, Kitasato University, Aomori 034-8628 and ${ }^{3)}$ Kohiruimaki Animal Medical Service, Aomori \\ 039-2683, Japan
}

\begin{abstract}
The purpose of this study was to determine the relationships between conception rate and other parameters before estrus synchronization with a Controlled Internal Drug Release Device (CIDR) and estradiol benzoate (EB). In the estrus synchronization program, animals were injected with $2 \mathrm{mg}$ EB and then received a CIDR. Seven days later, the CIDR was removed and the animals were given an injection of Prostaglandin $\mathrm{F}_{2 \alpha}$. Twenty-four hours later, they received an injection of $1 \mathrm{mg}$ EB, and they were artificially inseminated $24 \mathrm{~h}$ after that. This program was applied to 258 Holstein cows in Tohoku-machi (Aomori, Japan). Blood was collected at the beginning of the program, and the conception rate was determined about 40 days after insemination. The relationships among conception rate, blood biochemical values, age, body condition score and days in milk were statistically analyzed to determine better conditions for cow conception. The conception rate of the cows in the high progesterone group (more than $1 \mathrm{ng} / \mathrm{ml}$, $\mathrm{P}_{4}+$ ) was significantly higher than that of the low progesterone group (less than $1 \mathrm{ng} / \mathrm{ml}, \mathrm{P}_{4}-; 47.9 \%$ vs. $28.6 \% \mathrm{P}<0.01$ ). In the $\mathrm{P}_{4}$ - groups, the serum phospholipid level was significantly higher in the conception group than in the nonconception group, and the same tendency was seen in the $\mathrm{P}_{4}+$ groups. Blood urea nitrogen (BUN), albumin (Alb), and total cholesterol (TChol) were significantly higher in the conception group compared with the non-conception group, but no with $\mathrm{P}_{4}$ was observed. We concluded that 1 ) the conception rate of the $\mathrm{P}_{4}$ - group was remarkably low, that 2) the low conception rate and low $\mathrm{P}_{4}$ level was related to a low PL level and that 3) BUN, Alb and TChol were higher in the conception group, although no relation with $\mathrm{P}_{4}$ was found.
\end{abstract}

Key words: Conception rate, Controlled Internal Drug Release Device (CIDR), Estrus synchronization program, Holstein cow

(J. Reprod. Dev. 54: 214-216, 2008)

D ecline of the conception rate and extension of the calving interval in the dairy cow resulted in economic losses. In recent years, decline of the conception rate has become a serious problem $[1,2]$. One problem related to this is low fertilization resulting from an unsuitable nutrition status after calving. Some researchers have shown that low energy intake or body condition score (BCS) causes decreased conception rates [3, 4]. Milking requires expenditure of energy, and if the animal's BCS is low, increase of the negative energy balance (NEB) causes a negative influence on breeding function.

Another problem is that the estrus signs become weak and AI timing is unsuitable [5]. To solve these problems, some estrus synchronization programs, such as ovsynch, heatsynch [6], quicksynch [7] and modified programs using a Controlled Internal Drug Release (CIDR) have been developed. In this study, a synchronizing method that utilizes EB and a CIDR was used to clarify the influence of nutrition and internal secretion state at the time of synchronization start.

Accepted for publication: February 4, 2008

Published online: March 7, 2008

H. Miura (e-mail: miurah@vmas.kitasato-u.ac.jp)
Materials and Methods

\section{Animals}

A total of 258 lactating Holstein dairy cows from 13 herds in Tohoku-machi (Aomori, Japan) were used in the present study. Mean days in milk (DIM), BCS (on a scale from 1 to 5) and age were $123.7 \pm 74.8$ days, $2.6 \pm 0.4$ and $4.2 \pm 1.8$ years, respectively.

\section{Breeding program and pregnancy diagnosis}

The breeding program was a CIDR short program widely used in Japan. The estrus synchronization program, which used a CIDR (CIDR-B; InterAg, Hamilton, New Zealand) and estradiol benzoate (EB; Ginandoul; Sankyo, Tokyo, Japan), is shown in Fig. 1. The cows were injected intramuscularly with EB $2 \mathrm{mg}$, and a CIDR was intravaginally inserted and left in place on Day 0. On Day 7, the CIDR was removed, and $25 \mathrm{mg}$ prostaglandin $\mathrm{F}_{2 \alpha}$ ( $\mathrm{PGF}_{2 \alpha}$; Pronalgon F; Pharmacia, Tokyo, Japan) was administered intramuscularly. On Day 9, the cows were administered $1 \mathrm{mg} \mathrm{EB}$ to bring them into heat, and AI was performed on Day 10. Forty days after AI, pregnancy was determined by rectal palpation. 


\section{Blood biochemistry}

Blood samples were collected at the beginning of the breeding program and centrifuged to separate the plasma. Total protein (TP), glutamate oxaloacetate transaminase (GOT), total cholesterol (TChol), blood urea nitrogen (BUN), calcium (Ca), inorganic phosphorus (iP), magnesium (Mg), phospholipid (PL) and albumin (Alb) levels in the plasma were measured using an AU 400 autoanalyzer (Olympus, Tokyo, Japan) at the Animal Hospital of Kitasato University. Progesterone $\left(\mathrm{P}_{4}\right)$ levels were measured by enzyme-linked immunosorbent assay (ELISA) in the Department of Clinical Veterinary Theriogenology of Kitasato University [8].

\section{Data analysis}

Based on $\mathrm{P}_{4}$ concentration, the cows were divided into two groups as follows, 1) the $\mathrm{P}_{4}+$ group, which had $\mathrm{P}_{4}$ levels of more than $1 \mathrm{ng} / \mathrm{ml}$, and 2) the $\mathrm{P}_{4}$ - group, which had $\mathrm{P}_{4}$ levels of less than

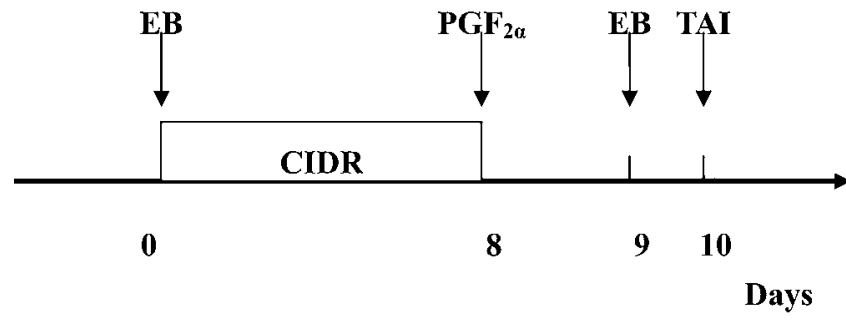

Fig. 1. Estrus synchronization program using a CIDR. Two mg EB and a CIDR were administered on Day 0. The CIDR was left in place and 25 mg PGF $_{2 \alpha}$ was administered on Day 7. One mg EB was administered on Day 9, and AI was performed on Day 10.
$1 \mathrm{ng} / \mathrm{ml}$. The conception rates of the $\mathrm{P}_{4}+$ and $\mathrm{P}_{4}-$ groups were calculated, and differences were evaluated using the Chi- square test.

The effects of $\mathrm{P}_{4}\left(\mathrm{P}_{4}+\right.$ and $\mathrm{P}_{4}$ - groups) and conception (conception and non-conception groups) on blood biochemistry values, age, DIM and BCS were assessed using two-way analysis of variance (ANOVA) and a post hoc test (Turkey's test). Statistical analyses were conducted using JSTAT for Windows (programmed by M Satoh; Vector, Tokyo, Japan).

\section{Results}

Of the 258 cows, 106 conceived, and the conception rate was $41.1 \%$.

There were 167 cows in the $\mathrm{P}_{4}+$ group, and 80 of the cows conceived. There were 91 cows in the $\mathrm{P}_{4}$ - group, and 26 of the cows conceived. The $\chi$-square tests revealed that the conception rate of the $\mathrm{P}_{4}+$ group (47.9\%) was significantly higher than that of the $\mathrm{P}_{4}$ group (28.6\%; Table 1$)$.

The results of two-way ANOVA are shown in Table 2. TChol, $\mathrm{PL}$, Alb and BUN were significantly higher in the conception groups $(\mathrm{P}<0.05)$, and the $\mathrm{P}_{4}$ level had no significant effect. Interaction between the $\mathrm{P}_{4}$ level and conception was only observed in relation to the PL level $(\mathrm{P}<0.05)$. The PL levels of the $\mathrm{P}_{4}+$ and conception, $\mathrm{P}_{4}+$ and non-conception, $\mathrm{P}_{4-}$ and conception and $\mathrm{P}_{4-}$ and non-conception groups were $270.7 \pm 50.6,229.7 \pm 32.1,218.0 \pm$ 16.2 and $171.8 \pm 48.1 \mathrm{mg} / \mathrm{dl}$ respectively. The Tukey multiple comparisons test showed that the PL levels of the $\mathrm{P}_{4}+$ and conception $(\mathrm{P}<0.01)$ and $\mathrm{P}_{4}-$ and conception groups $(\mathrm{P}<0.05)$ were significantly higher than that of the $\mathrm{P}_{4}$ - and non-conception group (Table 3). Therefore, the PL levels of the $\mathrm{P}_{4}$ - and non-conception

Table 1. Numbers of cows and conception rates of each group

\begin{tabular}{cccc}
\hline Group & Cows & Number of cows conceived & Conception rate (\%) \\
\hline $\mathrm{P}_{4^{-}}$ & 91 & 26 & $28.6^{\mathrm{a}}$ \\
$\mathrm{P}_{4}{ }^{+}$ & 167 & 80 & 47.9 \\
total & 258 & 106 & 41.1 \\
\hline
\end{tabular}

${ }^{a} \mathrm{P}<0.01$ for significant differences in conception rates between the $\mathrm{P}_{4-}$ and $\mathrm{P}_{4}+$ groups.

Table 2. Age, DIM, BCS and blood biochemistry values of the conception and non-conception cows

\begin{tabular}{llrr}
\hline & & Conception & Non-conception \\
\hline Age & $($ year) & $4.04 \pm 1.73$ & $4.36 \pm 1.85$ \\
Mean days in milk (DIM) & $($ day) & $131.6 \pm 80.5$ & $118.0 \pm 70.2$ \\
Body condition score (BCS) & & $2.55 \pm 0.40$ & $2.55 \pm 0.39$ \\
Total protein (TP) & $(\mathrm{mg} / \mathrm{dl})$ & $7.53 \pm 0.91$ & $7.44 \pm 0.90$ \\
Glutamate oxaloacetate transaminase (GOT) & $(\mathrm{IU} / \mathrm{l})$ & $79.0 \pm 20.1$ & $76.8 \pm 29.4$ \\
Total cholesterol (Tchol) & $(\mathrm{mg} / \mathrm{dl})$ & $214.0 \pm 50.3^{\mathrm{a}}$ & $201.8 \pm 53.1$ \\
Blood urea nitrogen (BUN) & $(\mathrm{mg} / \mathrm{dl})$ & $12.3 \pm 3.6^{\mathrm{a}}$ & $11.8 \pm 3.0$ \\
Calcium (Ca) & $(\mathrm{mg} / \mathrm{dl})$ & $8.92 \pm 0.76$ & $8.81 \pm 0.78$ \\
Inorganic phosphorus (iP) & $(\mathrm{mg} / \mathrm{dl})$ & $5.84 \pm 0.98$ & $5.72 \pm 1.05$ \\
Magnesium (Mg) & $(\mathrm{mg} / \mathrm{dl})$ & $2.29 \pm 0.22$ & $2.29 \pm 0.66$ \\
Phospholipid (PL) & $(\mathrm{mg} / \mathrm{dl})$ & $237.2 \pm 51.6^{\mathrm{a}, \mathrm{b}}$ & $219.3 \pm 57.5$ \\
Albumin (Alb) & $(\mathrm{g} / \mathrm{dl})$ & $3.60 \pm 0.31^{\mathrm{a}}$ & $3.51 \pm 0.35$ \\
\hline
\end{tabular}

${ }^{a} \mathrm{P}<0.05$ for significant differences between the conception and non-conception groups.

${ }^{\mathrm{b}}$ There was interaction between the effects of $\mathrm{P}_{4}$ level and conception $(\mathrm{P}<0.05)$. 
Table 3. The PL levels (mg/dl) of the conception and nonconception cows in the $\mathrm{P}_{4-}$ and $\mathrm{P}_{4}+$ groups

\begin{tabular}{lcc}
\hline & Conception & Non-conception \\
\hline $\mathrm{P}_{4-}$ & $218.0 \pm 16.2^{\mathrm{a}}$ & $171.8 \pm 48.1$ \\
$\mathrm{P}_{4^{+}}$ & $270.7 \pm 50.6^{\mathrm{b}}$ & $229.7 \pm 32.1$ \\
\hline
\end{tabular}

a Significantly higher than the $\mathrm{P}_{4}-/$ non-conception groups $(\mathrm{P}<0.05)$.

b Significantly higher than the $\mathrm{P}_{4}-/$ non-conception groups $(\mathrm{P}<0.01)$.

group was significantly lower than those of the $\mathrm{P}_{4}+$ and conception and $\mathrm{P}_{4}+$ and non-conception groups, but that of the $\mathrm{P}_{4}+$ and nonconception group was not.

\section{Discussion}

In this study, we clearly showed that a low $\mathrm{P}_{4}$ level at the start of this breeding program suppresses the conception rate. It has been reported that poor nutrition suppresses the activity of the ovaries and $\mathrm{P}_{4}$ secretion and causes low conception rates [9]. Yamada [5] reported that the conception rate after the Ovsynch program is high in cows with a BCS of 3.75 during the dry period and 3.0 on the day of Ovsynch. In this study, the BCS at the start of the synchronization program was 2.55 regardless of conception or non-conception, and this lower BCS indicated that the nutritional status of the examined cows was lower than the optimal nutritional level for treatment with a fixed-time artificial insemination program.

The effects of $\mathrm{P}_{4}$ and conception showed interaction on the PL level, and this suggested that there is a relationship between the levels of plasma PL and $\mathrm{P}_{4}$ and the conception rate. Table 3 indicates that in low $\mathrm{P}_{4}$ groups, $\mathrm{PL}$ of conception group is significantly higher than that of non-conception group, but not in high $\mathrm{P}_{4}$ groups.

Some researchers have shown that there is a relationship between fat and ovarian activity. Ryan et al. $[10,11]$ indicated that a high fat diet causes increased frequency of luteal activity and alterations in specific aspects of ovarian steroidogenic potential. Other researchers have shown that PL activates protein kinase, which controls luteal cells [12,13], and that lipoprotein, which is composed of PL, regulates $\mathrm{P}_{4}$ production in luteal cells $[14,15]$.

Therefore, we hypothesized that a low plasma PL level inactivates the luteal body. In this study, some of the $\mathrm{P}_{4}-$ cows had insufficient levels of PL for activation of the luteal body, so the luteal body of the next cycle, which maintains pregnancy, was also inactive, causing a decline in the conception rate. This mechanism did not work in the $\mathrm{P}_{4}$ - cows that had sufficient levels of PL nor in the $\mathrm{P}_{4}+$ cows and this may be the cause of the low conception rate in the $\mathrm{P}_{4}$ - group.

Interestingly, the $\mathrm{P}_{4}$ level at the beginning of the program did not affect Alb, BUN or TChol, although the conception rate decreased as their levels increased in the present study. Therefore, there may be other factors unrelated to luteal body acitivity and $\mathrm{P}_{4}$ that reduce the conception rate, such as those related to Alb, BUN, TChol and probably PL. Further research is required to determine these mechanisms.

This study suggests that a low $\mathrm{P}_{4}$ level at the start of the breeding program using a CIDR and EB caused the low conception rate and that this was related to a low PL level. It also suggested that BUN, Alb and TChol also affect the conception rate, regardless of the level of $\mathrm{P}_{4}$.

\section{References}

1. Formigoni A, Trevisi E. Transition cow: interaction with fertility. Vet Res Commun 2003; 27: 143-152.

2. Royal M, Mann GE, Flint AP. Strategies for reversing the trend towards subfertility in dairy cattle. Vet J 2000; 160: 53-60.

3. Butler WR, Smith RD. Interrelationships between energy balance and postpartum reproductive function in dairy cattle. J Dairy Sci 1989; 72: 767-783.

4. Ferguson JD, Chalupa W. Impact of protein nutrition on reproduction in dairy cows. I Dairy Sci 1989; 72: 746-766.

5. Yamada K. Development of ovulation synchronization and fixed time artificial insemination in dairy cows. J Reprod Dev 2005; 51: 177-186.

6. Stevenson JS, Tiffany SM, Lucy MC. Use of estradiol cypionate as a substitute for GnRH in protocols for synchronizing ovulation in dairy cattle. J Dairy Sci 2004; 87: 3298-3305

7. Bartolome JA, Sozzi A, McHale J, Melendez P, Arteche AC, Silvestre FT, Kelbert D, Swift K, Archbald LF, Thatcher WW. Resynchronization of ovulation and timed insemination in lactating dairy cows, II: assigning protocols according to stages of the estrous cycle, or presence of ovarian cysts or anestrus. Theriogenology 2005; 63: 16281642 .

8. Munro C, Stabenfeldt G. Development of a microtitre plate enzyme immunoassay for the determination of progesterone. J Endocrinol 1984; 101: 41-49.

9. Armstrong DG, McEvoy TG, Baxter G, Robinson JJ, Hogg CO, Woad KJ, Webb R Sinclair KD. Effect of dietary energy and protein on bovine follicular dynamics and embryo production in vitro: associations with the ovarian insulin-like growth factor system. Biol Reprod 2001; 64: 1624-1632.

10. Ryan DP, Bao B, Griffith MK, Williams GL. Metabolic and luteal sequelae to heightened dietary fat intake in undernourished, anestrous beef cows induced to ovulate. J Anim Sci 1995; 73: 2086-2093.

11. Ryan DP, Spoon RA, Williams GL. Ovarian follicular characteristics, embryo recovery and embryo viability in heifers fed high fat diets and treated with follicle-stimulating hormone. J Anim Sci 1992; 70: 3505-3513.

12. Davis JS, Clark MR. Activation of protein kinase in the bovine corpus luteum by phospholipid and $\mathrm{Ca}^{2+}$. Biochem J 1983; 214: 569-574.

13. Okuda K, Uenoyama Y, Lee KW, Sakumoto R, Skrzynski DJ. Progesterone stimulation by prostaglandin F2 alpha involves the protein kinase $C$ pathway in cultured bovine luteal cells. J Reprod Dev 1998; 44: 79-84.

14. Bao B, Thomas MG, Williams GL. Regulatory roles of high-density and low-density lipoproteins in cellular proliferation and secretion of progesterone and insulin-like growth factor I by enriched cultures of bovine small and large luteal cells. J Anim Sci 1997; 75: 3235-3245.

15. Carroll DJ, Grummer RR, Mao FC. Progesterone production by cultured luteal cells in the presence of bovine low- and high-density lipoproteins purified by heparin affinity chromatography. Anim Sci 1992; 70: 2516-2526. 